\title{
THE FEASIBILITY OF USING COMPUTER-BASED MODELS FOR REDUCING THE RISKS OF COMPLICATIONS ASSOCIATED WITH TEMPORARY DENTURES
}

\author{
Bagryantseva NV1,2凶, Gazhva SI ${ }^{1}$, Baranov AA², Shubin LB², Bagryantsev VA², Bagryantseva OV² \\ ${ }_{1}^{1}$ Privolzhsky Research Medical University, Nizhny Novgorod, Russia \\ 2 Yaroslavl State Medical University, Yaroslavl, Russia
}

\begin{abstract}
Contemporary prosthetic dentistry has a vast arsenal of solutions for completely edentulous patients. However, it is crucial to consider a variety of factors that can cause complications in patients wearing temporary dentures in the osseointegration period. The aim of this study was to retrospectively analyze the medical records of completely edentulous patients wearing temporary removable or fixed dentures in the osseointegration period, to identify the risk factors for complications and to calculate the odds of adverse events. We performed a multivariate analysis and developed a computerized algorithm that could be used to facilitate selection of the proper denture type and material. The algorithm demonstrates high sensitivity and specificity: 94.37 (76.2 : 98.7$)$ and 92.56 (79.8 : 97.6$)$, respectively; the AUC value is 0.921 (0.843: 0.963). We are planning to develop a software based on the proposed algorithm that would help the dentist to make a more objective decision when selecting the type of temporary denture and its material.
\end{abstract}

Keywords: dental implants, osseointegration, temporary prosthesis, risks, odds, computer-based model

Author contribution: Bagryantseva NV — study design, data acquisition, analysis and interpretation, manuscript editing: Gazhva SI — study planning and manuscript editing; Baranov AA — manuscript editing; Shubin LB — data analysis and interpretation; Bagryantsev VA, Bagryantseva OV — data acquisition and preparing the manuscript draft.

Compliance with ethical standards: the study was approved by the Ethics Committee of Privolzhsky Research Medical University (Protocol No.10 dated December 25, 2017)

$\triangle$ Correspondence should be addressed: Natalia V. Bagryantseva

March 8, d. 1, kor. 2, kv. 71, Yaroslavl, 150002; nbogryanceva@mail.ru

Received: 25.07.2019 Accepted: 09.08.2019 Published online: 16.08.2019

DOI: $10.24075 /$ brsmu.2019.050

\section{ВОЗМОЖНОСТИ ИСПОЛЬЗОВАНИЯ КОМПЬЮТЕРНЫХ МОДЕЛЕЙ ДЛЯ СНИЖЕНИЯ РИСКОВ ПРИ ВРЕМЕННОМ ПРОТЕЗИРОВАНИИ}

Н. В. Багрянцева ${ }^{1,2 凶}$, С. И. Гажва 1 , А. А. Баранов², Л. Б. Шубин², В. А. Багрянцев², О. В. Багрянцева²

1 Приволжский исследовательский медицинский университет, Нижний Новгород, Россия

2 Ярославский государственный медицинский университет, Ярославль, Россия

Современная ортопедическая стоматология обладает большим арсеналом решений для оказания помощи пациентам с полной вторичной адентией, что, однако, может вызывать ряд проблем. При выборе вида временного протеза на момент остеоинтеграции дентальных имплантатов необходимо учитывать большое количество факторов, возникающих при различных клинических ситуациях. Целью работы было в ходе ретроспективного анализа медицинской документации пациентов с полной вторичной адентией и установленными временными протезами (покрывными съемными и условносъемными) на момент остеоинтеграции дентальных имплантатов оценить факторы риска и отношение шансов их реализации в развитии осложнений на этот период. Осуществлено многомерное математико-статистическое моделирование с построением компьютерного алгоритма принятия решений в выборе типа протеза и материала для его изготовления. Алгоритм (модель) обладает высокими значениями чувствительности и специфичности 94,37 (76,2 : 98,7) и 92,56 (79,8 : 97,6), при площади под характеристической кривой, равной 0,921 (0,843 : 0,963). Используя автоматизацию поэтапного алгоритма, планируется создать компьютерную программу для повышения степени объективности при выборе способа временного протезирования и материала протеза.

Ключевые слова: дентальная имплантация, остеоинтеграция, временное протезирование, риски, шансы, компьютерная модель

Информация о вкладе авторов: Н. В. Багрянцева - разработка дизайна исследования, получение данных, анализ и интерпретация данных, редактирование рукописи; С. И. Гажва - планирование исследования, редактирование рукописи; А. А. Баранов - редактирование рукописи; Л. Б. Шубин - анализ и интерпретация данных; В. А. Багрянцев, О. В. Багрянцева — сбор данных, подготовка черновика рукописи.

Соблюдение этических стандартов: исследование одобрено этическим комитетом ФГБОУ ВО НижГМА Минздрава России (протокол № 10 от 25 декабря 2017 г.)

$\triangle$ Для корреспонденции: Наталья Владимировна Багрянцева ул. 8 марта, д. 1, кор. 2, кв. 71, г. Ярославль, 150002; nbogryanceva@mail.ru

Статья получена: 25.07.2019 Статья принята к печати: 09.08.2019 Опубликована онлайн: 16.08.2019

DOI: $10.24075 /$ vrgmu.2019.050

To date, dental implant surgery has become a routine practice that boasts good long-term outcomes [1, 2]. Its results can be predicted even before treatment commences. Once an implant is placed in the jawbone, the patient can be offered temporary dentures, either removable or fixed, available in a variety of materials [3].

However, approaches to temporary tooth restoration during osseointegration in completely edentulous patients are controversial [4]. The analysis of the literature reveals the need for an adequate algorithm that would facilitate the right choice of a provisional denture and stresses the importance of a mathematically accurate approach to the rehabilitation of edentulous patients [2] that will minimize the risks of poor outcomes or complications and improve the quality of life for such parents.

\section{METHODS}

We conducted a retrospective analysis of medical records obtained from Yaroslavl regional dental clinic (Yaroslavl, Russia). Specifically, we studied the dental histories of patients (form 043/u) and reports of oral surgeons (form 039-4/u) dating back 
to 2015 to 2019. The following inclusion criteria were applied: any sex or age and acquired absence of teeth. Patients with decompensated conditions, buccal exostosis, cancer, or blood clotting disorders were excluded from the study. Information about the causes of teeth loss, patients' complaints, treatment planning, and the type of temporary dental prostheses was retrieved from the records. Implant materials were analyzed separately. The obtained data were saved into cross-tables, and the necessary codes were submitted. In total, we analyzed the medical records of 102 patients and reports of 1 oral surgeon. Of those patients, 34 were completely edentulous and 68 retained either loose teeth or healthy roots, which were removed in the course of treatment. All 102 patients received dental implants and temporary dentures. Considering the objective of this work, the patients were distributed into two groups. Group 1 included patients with successful osseointegration ( $n=73$ ); group 2 comprised patients who developed complications $(n=29)$. All patients underwent panoramic radiography aimed to evaluate the bone around the implant and the quality of osseointegration. The examination was performed three times using a Strato 2000d OPG machine (Villa Sistemi Medicali; Italy). Besides, intraoral periapical radiographs were taken using an EzSensor radiovisiography imaging system (Vatech; South Korea). An MRI scan was also ordered for some patients (a Brilliance 64 MRI scanner; Philips; Netherlands).

Jawbone atrophy and quality were assessed using the classification developed by Lekholm and Zarb [5] based on jaw density and structure. The condition of oral mucosa was assessed using the conventional classification proposed by Supple (Table 1). Comorbidities and health compromising behaviors were also noted.

Statistical analysis was performed in Statistica ver. 12, 2014 (StatSoft Inc.; USA) and MedCalc Statistical Software ver. 18.2.1, 2018 (MedCalc Software bvba; Ostend, Belgium). We identified risk factors, calculated their odds and the 95\% $\mathrm{Cl}$. Variables characterized by a high probability of occurrence

Table 1. Supple's classification of oral mucosa served as a basis for our multivariate statistical models that were built using logistic regression. ROC-curve analysis was applied to assess the quality of the models.

\section{RESULTS}

The initial analysis revealed that in the osseointegration period, the patients developed a variety of complications associated with temporary dentures. The total number of complications was 29 , occurring in $28 \%$ of the studied patients. The most common (34\%) problem was difficulty adapting to overdentures. Oral mucositis (20\%) and denture fractures or breakages (20\%) ranked second. Peri-implantitis and allergy to denture materials (plastic monomers) were the third most common problem, accounting for $10 \%$ of complications each. Bad breath and implant instability occurred in 3\% of the complicated cases.

Comparison of Groups 1 and 2 allowed us to draw a mathematically accurate profile of statistically significant risk factors. When analyzing the risk of a particular event (a complication) in the patients with acquired edentulism who were wearing provisional dentures in the osseointegration period, we calculated its odds. The risk was understood as an exposure that increased the likelihood of a particular complication. Relative risks were calculated as a ratio of frequency of the complication in the group at risk for this event to the frequency of this event in the control group. Six statistically significant risk factors were identified, including the severity of jawbone atrophy (grades C, D, or E, according to Lekholm and Zarb's classification), the density of cortical and cancellous bones (same classification, types III and IV), the condition of oral mucosa (types 3 and 4, Supple's classification), allergy to monomer components of the denture, poor mouth hygiene and health compromising behaviors (Table 2).

In order to characterize the relationship between the complication and the corresponding risk factor, we calculated the odds ratio (the ratio of the odds of the event occurring to the

\begin{tabular}{|l|l|l|}
\hline Grade 1 & Ideal mouth & Well-defined alveolar bones covered with a slightly supple pale pink mucous membrane, showing no signs of pathology \\
\hline Grade 2 & Hard mouth & Atrophied thickened dry mucosa, attaches to the alveolar ridge closer than in Grade 1 \\
\hline Grade 3 & Soft mouth & A hypertrophic lax mucous membrane, low alveolar bones \\
\hline Grade 4 & Flabby ridge & Excessive flabby tissue, easily displaced by applying slight pressure, can get pinched between the denture and the alveolar ridge \\
\hline
\end{tabular}

Table 2. Relative risks for complications associated with temporary dentures

\begin{tabular}{|l|c|c|c|}
\hline \multicolumn{1}{|c|}{ Risk factor } & Relative risk & "-" 95\% Cl & " $95 \% \mathrm{Cl}$ \\
\hline Severity of bone atrophy, grades C, D, or E & 1.7997 & 0.5518 & 2.1929 \\
\hline Bone quality, classes III and IV & 0.9858 & 0.4542 & 2.2258 \\
\hline Oral mucosa condition, types 3 and 4 & 1.3947 & 0.5566 & 2.2588 \\
\hline Allergy + & 0.8716 & 0.3044 & 2.2069 \\
\hline Poor mouth hygiene + & 0.7891 & 0.2391 & 1.9864 \\
\hline Smoking + & 0.5333 & 0.2593 & 2.6781 \\
\hline
\end{tabular}

Table 3. Odds ratios for complications associated with temporary dentures

\begin{tabular}{|l|c|c|c|}
\hline \multicolumn{1}{|c|}{ Risk factor } & Odds ratio & "-" 95\% Cl \\
\hline Bone atrophy, grade C & 1.8879 & 0.1518 & 0.1542 \\
\hline Bone atrophy, grade D & 1.5858 & 0.1566 & 2.2854 \\
\hline Bone atrophy, grade E & 1.2845 & 0.2044 & 2.2546 \\
\hline Oral mucosa condition, type 3 & 1.2143 & 0.2721 & 2.2588 \\
\hline Oral mucosa condition, type 4 & 1.1947 & 0.2593 & 1.9864 \\
\hline Allergy + & 0.8333 & 0.2694 & 2.6781 \\
\hline Poor mouth hygiene + & 0.6891 & 0.2443 \\
\hline Smoking + & 0.4222 & 1.8871 \\
\hline
\end{tabular}


odds of the event not occurring). We found that 6 identified risk factors had a high probability of occurrence. However, because some factors, including jaw bone atrophy and the condition of oral mucosa, could be further graded into different degrees of severity and types, the likelihood of their occurrence varied. For example, bone atrophy was represented by 3 probabilistic states corresponding to grades C, D, or E of the applied classification; the condition of oral mucosa was represented by types 3 and 4 of the same classification $[2,6,7]$ (Table 3).
Considering the obtained results, we decided to improve the accuracy of risk prediction by employing a multivariate analysis. Using logistic regression, we were able to identify the relationships between independent and response variables. We also assessed the mutual influence of the variables and the contribution of each variable to the classification. Results of statistical modeling are presented in Table 4.

The constructed model was characterized by a high level of significance. The values of both regression coefficients

Table 4. Characteristics of the regression model for the choice of a temporary dental prosthesis (TDPC)

\begin{tabular}{|l|c|}
\hline \multicolumn{1}{|c|}{ Parameter } & TDPC \\
\hline Level of significance & $p=0.001$ \\
\hline Coefficient of determination, Cox \& Snell's R ${ }^{2}$ & 0.834 \\
\hline Coefficient of determination, Nagelkerke's R ${ }^{2}$ & 0.758 \\
\hline Hosmer \& Lemeshow test, significance & $p=0.594$ \\
\hline Concordance correlation coefficient & 0.8946 \\
\hline
\end{tabular}

Table 5. Standardized regression coefficients included in the model for the choice of TDPC

\begin{tabular}{|l|c|c|c|}
\hline \multicolumn{1}{|c|}{ Variable } & Coefficient & Standard error & Wald test \\
\hline Severity of bone atrophy & -2.13953 & 0.40234 & 0.1203 \\
\hline Bone quality & 3.58284 & 0.47428 & 11.1382 \\
\hline Condition of oral mucosa & -1.85714 & 0.83806 & 11.6227 \\
\hline Allergy & 3.46292 & 0.44173 & 10.968 \\
\hline Poor mouth hygiene & 1.55758 & 0.41697 & 13.954 \\
\hline Smoking & 0.056017 & 0.070499 & 0.6314 \\
\hline Constant & -8.64908 & 85.2702 & 0.01029 \\
\hline
\end{tabular}

Table 6. Operational characteristics of the model for the choice of TDPC

\begin{tabular}{|c|c|}
\hline Parameter & TDPC \\
\hline Area under curve (AUC) & 0.921 \\
\hline Mean squared error ${ }^{a}$ & 0.0524 \\
\hline$-95 \% \mathrm{Cl}(\mathrm{AUC})$ & 0.873 \\
\hline +95\% Cl (AUC) & 0.963 \\
\hline$z$-score & 9.645 \\
\hline Significance, $p$ (area $=0.5$ ) & 0.001 \\
\hline Youden J & 0.8284 \\
\hline Optimal cut-off value & $\leq 1.43$ \\
\hline Sensitivity & 94.37 \\
\hline$-95 \% \mathrm{Cl}(\mathrm{Se})$ & 76.2 \\
\hline +95\% Cl (Se) & 98.7 \\
\hline Specificity & 92.56 \\
\hline$-95 \% \mathrm{Cl}(\mathrm{Sp})$ & 79.8 \\
\hline$+95 \% \mathrm{Cl}(\mathrm{Sp})$ & 97.6 \\
\hline +Likelihood ratio (+LR) & 7.31 \\
\hline$-95 \% \mathrm{Cl}(+\mathrm{LR})$ & 2.5 \\
\hline$+95 \% \mathrm{Cl}(+\mathrm{LR})$ & 21.4 \\
\hline -Likelihood ratio (-LR) & 0.18 \\
\hline$-95 \% \mathrm{Cl}(-\mathrm{LR})$ & 0.08 \\
\hline$+95 \% \mathrm{Cl}(-\mathrm{LR})$ & 0.4 \\
\hline +Prognostic value (+PV) & 89.9 \\
\hline$-95 \% \mathrm{Cl}(+\mathrm{PV})$ & 75.3 \\
\hline$+95 \% \mathrm{Cl}(+\mathrm{PV})$ & 96.3 \\
\hline -Prognostic value (-PV) & 82.2 \\
\hline$-95 \% \mathrm{Cl}(-\mathrm{PV})$ & 67.2 \\
\hline$+95 \% \mathrm{Cl}(-\mathrm{PV})$ & 91.3 \\
\hline
\end{tabular}


of determination $\left(R^{2}\right)$ were quite high, suggesting a relatively high stability of our prediction model. The obtained value of the concordance correlation coefficient spoke in favor of this conclusion. Using the Hosmer-Lemeshow test, we assessed the goodness of fit by comparing the observed and expected frequencies. In our case, the fit was good, with over $5 \%$ statistical significance Standardazied regression coefficients included in the model and presented in Table 5 reflected all stages of the algorithm.

The following logistic regression equation was proposed based on the results of multivariate modeling:

$$
\mathrm{F}=c+k_{1} x_{1}+k_{2} x_{2}+\ldots+k_{n} x_{n}
$$

where $\mathrm{F}$ is a dependent variable; $\mathrm{c}$ is a constant; $k_{i}$ is a coefficient of the regression function; $x_{i}$ is a predictor (a variable).
Logistic regression and the use of the abovementioned equation for determining individual $F$ values included ROCcurve analysis. The following parameters were calculated: an area under curve (AUC), the Youden index, an optimal cut-off value, sensitivity and specificity, positive and negative likelihood ratios (LR), positive and negative predictive values (PV), and 95\% Cl for each parameter (Table 6).

\section{DISCUSSION}

Unsurprisingly, the density of cortical and cancellous bone (classes III and IV according to Lekholm and Zarb's classification) was the leading risk factor for complications associated with temporary dental prostheses, because the success of denture placement is largely determined by bone density. The second

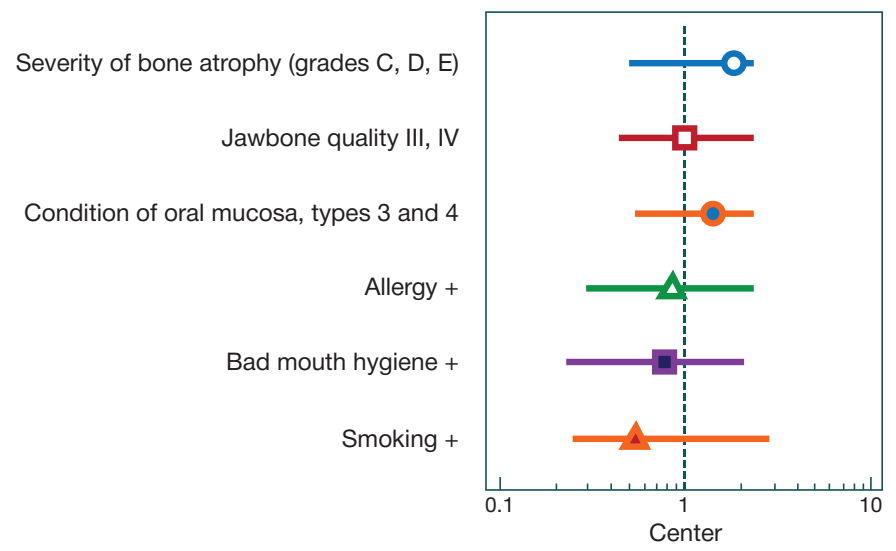

Fig. 1. A forest plot showing risk factors for the complications associated with temporary dental prostheses

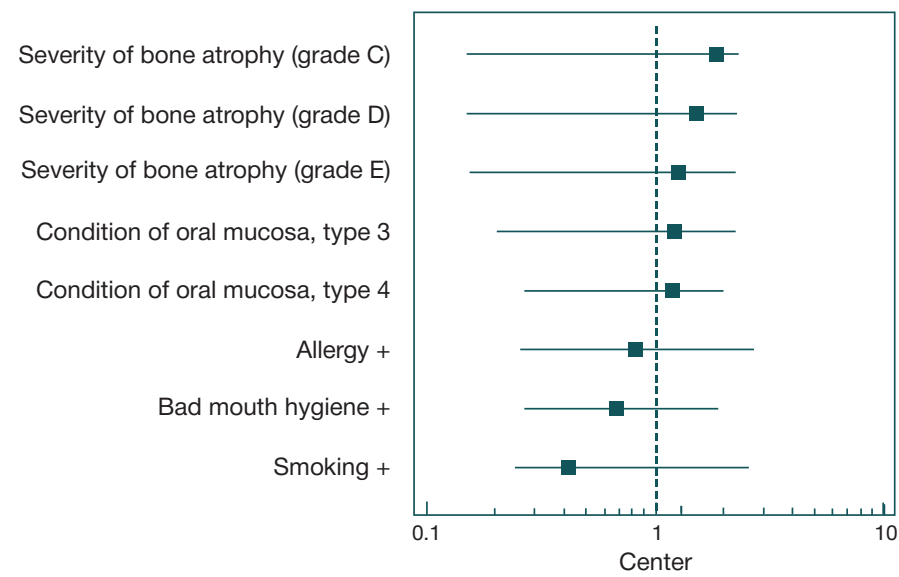

Fig. 2. A forest plot showing the odds ratios of the risk factors for the complications associated with temporary dental prostheses

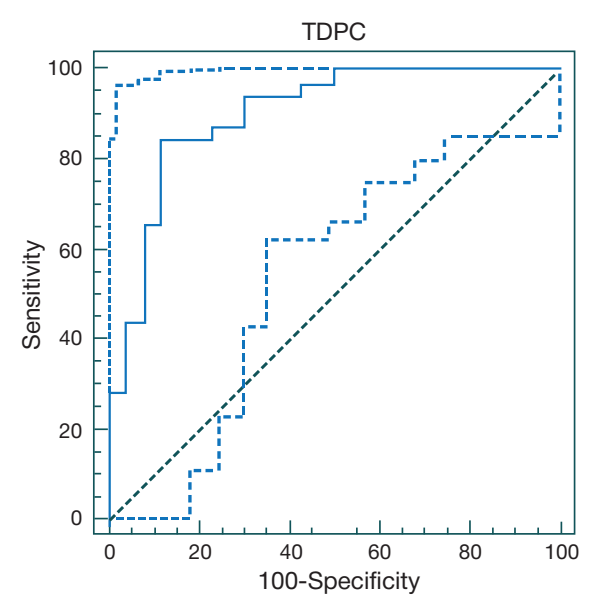

Fig. 3. A ROC curve for the prediction model facilitating the choice of TDPC 
most significant risk factor was allergy to the plastic monomer components of the denture. The severity of bone atrophy (Lekholm and Zarb's classification) and the condition of oral mucosa (types 3 and 4) ranked third and fourth in importance, respectively. Poor mouth hygiene and health-compromising habits (smoking) also contributed to the development of complications [2, 4]. Fig. 1 shows a forest plot for the listed risk factors.

The odds of the observed complications associated with temporary dentures worn by edentulous patients in the osseointegration period can be presented in the following descending order: type 4 condition of oral mucosa (Supple's classification), allergy to denture material, type 3 condition of oral mucosa, bone atrophy (grades E and D), bad mouth hygiene, bone atrophy (grade C), and smoking. Fig. 2 shows a forest plot for the odds ratios.

Considering the values of operational characteristic of the model, we think the proposed computerized algorithm is a feasible tool that assists selection of a proper temporary dental prosthesis. Sensitivity and specificity $(95 \% \mathrm{Cl})$ of the proposed algorithm are high; the same is true for the absolute values.
The positive likelihood ratio is 7 times higher than the negative likelihood ratio; the positive prognostic value exceeds the negative almost sevenfold. These facts suggest stability of our prediction model confirmed by the AUC value of 0.921 shown in Fig. $3[8,9]$.

\section{CONCLUSIONS}

1. The severity of jawbone atrophy and the density of cortical and cancellous bone are the most important factors that should be considered when selecting a temporary removable or fixed denture for edentulous patients in the osseointegration period. 2. It is critical to assess the condition of oral mucosa in order to avoid complications. 3. If the patient is a smoker or has bad hygiene habits, he/she should be offered a removable denture. 4. If the patient is not allergic to plastic and maintains good hygiene, he/she can be offered temporary dentures made of any kind of plastic. 5. Based on the proposed algorithm, we are planning to develop a software that would help the dentist to make a more objective decision when selecting the denture type and material.

\section{References}

1. McRory ME, Cagna DR. A technique for fabricating single screwretained implant-supported interim crowns in conjunction with implant surgery. J Prosthet Dent. 2014 Jun; 111 (6): 455-9. PubMed PMID: 24461941. DOI: 10.1016/j.prosdent.2013.11.005.

2. Aghaloo T, Pi-Anfruns J, Moshaverinia A, et al. The Effects of Systemic Diseases and Medications on Implant Osseointegration: A Systematic Review. Int J Oral Maxillofac Implants. 2019 Suppl; (34): 35-49. PubMed PMID: 31116832. DOI: 10.11607/ jomi.19suppl.g3.

3. Parvini P, Saminsky M, Stanner J, et al. Discomfort/pain due to periodontal and peri-implant probing with/without platform switching. Clin Oral Implants Res. 2019 Jul 20. PubMed PMID: 31325382. DOI: $10.1111 / \mathrm{dr} .13513$

4. Radzewski R, Osmola K. Osseointegration of Dental Implants in Organ Transplant Patients Undergoing Chronic Immunosuppressive Therapy. Implant Dent. 2019 Jul 12. PubMed PMID: 31306295DOI: 10.1097/ID.0000000000000916.

5. Lekholm U, Zarb G. Tissue-Integrated Prostheses Osseointegration in

\section{Литература}

1. McRory ME, Cagna DR. A technique for fabricating single screwretained implant-supported interim crowns in conjunction with implant surgery. J Prosthet Dent. 2014 Jun; 111 (6): 455-9. PubMed PMID: 24461941. DOI: 10.1016/j.prosdent.2013.11.005.

2. Aghaloo T, Pi-Anfruns J, Moshaverinia A, et al. The Effects of Systemic Diseases and Medications on Implant Osseointegration: A Systematic Review. Int J Oral Maxillofac Implants. 2019 Suppl; (34): 35-49. PubMed PMID: 31116832. DOI: 10.11607/ jomi.19suppl.g3.

3. Parvini P, Saminsky M, Stanner J, et al. Discomfort/pain due to periodontal and peri-implant probing with/without platform switching. Clin Oral Implants Res. 2019 Jul 20. PubMed PMID: 31325382. DOI: $10.1111 / \mathrm{clr} .13513$.

4. Radzewski R, Osmola K. Osseointegration of Dental Implants in Organ Transplant Patients Undergoing Chronic Immunosuppressive Therapy. Implant Dent. 2019 Jul 12. PubMed PMID: 31306295DOI: 10.1097/ID.0000000000000916.

5. Lekholm U, Zarb G. Tissue-Integrated Prostheses Osseointegration in Clinical Dentistry. Chicago: Quintessence publishing, 1985; 199-210.

6. Hu Z, Wang X, Xia W, et al. Nano-Structure Designing Promotion Osseointegration of Hydroxyapatite Coated Ti-6Al-4V Alloy Implants in Diabetic Model. J Biomed Nanotechnol. 2019 Aug 1; 15 (8): 1701-13. PubMed PMID: 31219019. DOI: 10.1166/ jbn.2019.2812.

7. Mangano FG, lezzi G, Shibli JA, et al. Early bone formation around immediately loaded implants with nanostructured calciumincorporated and machined surface: a randomized, controlled histologic and histomorphometric study in the human posterior maxilla. Clin Oral Investig. 2017 Nov; 21 (8): 2603-11. PubMed PMID: 28154996. DOI: 10.1007/s00784-017-2061-y.

8. Широков И. Ю. Экспериментальное обоснование применения временных несъемных зубных протезов при дентальной имплантации [диссертация]. М., 2013.

9. Робакидзе Н. С., Лобановская А. А., Пекарчик Д. М. Применение временных протезных конструкций в период остеоинтеграции внутрикостных имплантатов. Институт стоматологии. 2016; (2): 78-9. 